\title{
Isolation and molecular identification of carbohydrase and protease producing Bacillus subtilis JCM 1465 isolated from Penen Hot Springs in North Sumatra, Indonesia
}

\author{
EDY FACHRIAL ${ }^{1}$, SARI ANGGRAINI ${ }^{1}$, HARMILENI ${ }^{2}$, TITANIA T. NUGROHO ${ }^{3}$, SARYONO $^{3, \bullet}$ \\ ${ }^{1}$ Laboratory of Molecular Biology, Faculty of Medicine, Universitas Prima Indonesia. Jl Belanga No.1, Medan 20111, North Sumatra, Indonesia. \\ ${ }^{2}$ Politeknik Teknologi Kimia Industri. Jl. Medan Tenggara No. 7, Medan 20228, North Sumatra, Indonesia \\ ${ }^{3}$ Department of Chemistry, Universitas Riau. Jl. Bina Widya Km. 12.5, Simpang Baru, Pekanbaru 28293, Riau, Indonesia. Tel.: +62-761-63273, ^email: \\ saryono@lecturer.unri.ac.id
}

Manuscript received: 29 September 2019. Revision accepted: 8 November 2019.

\begin{abstract}
Fachrial E, Anggraini S, Harmileni, Nugroho TT, Saryono. 2019. Isolation and molecular identification of carbohydrase and protease producing Bacillus subtilis JCM 1465 isolated from Penen Hot Springs in North Sumatra, Indonesia. Biodiversitas 20: 34933498. The application of enzymes industrially is increasing every year and thermophilic microbes are a promising source of these enzymes for industrial use due to their temperature stability. The aim of this study, therefore, was to isolate, characterize and identify the enzyme producer-thermophilic bacteria from the Penen Hot Spring in Deli Serdang, North Sumatra, Indonesia. In the experimental setup, carbohydrase activities including inulinase and amylase were determined by the formation of clear zone around the colonies after soaking with Lugol on the TSA medium supplemented with $1 \%$ inulin powder and $1 \%$ starch. Similarly, the protease activities were determined by the formation of clear zone around the colonies on Skim Milk Agar Medium. Then, of the 11 isolates, only one known as UTMP 12 showed maximum enzyme activity. The isolate was then characterized based on morphology and biochemistry and found to be Bacillus subtilis strain JCM 1465 (accession number NR 113265, homolog 99.72\%). Furthermore, this is the first study on carbohydrase and protease activities of Bacillus subtilis strain JCM 1465 and the result shows that the thermophilic bacteria are needed in the production of carbohydrase and protease.
\end{abstract}

Keywords: Carbohydrase, hot spring, protease, thermophilic bacteria

\section{INTRODUCTION}

A large number of reactions require enzymes as biocatalyst. Also, microbial enzymes have significant use in various areas such as the food, agriculture, chemicals, medicine, and energy industries. In addition, most enzymes require milder temperature and $\mathrm{pH}$ while catalyzing reactions. Also, the group of enzymes most frequently used for industrial purposes is carbohydrase and protease. The carbohydrases, on one hand, are involved in the hydrolysis of carbohydrates such as amylase, cellulase, inulinase, glucosyltransferase, etc, and most are obtained from microbial sources. According to Contesini et al. (2013), carbohydrase plays an important role in producing different types of sugar syrups, prebiotics, sweetener substitutes, etc. Additionally, amylase holds about $25-30 \%$ shares of the world enzyme market, drawing more attention due to its wide applications and economic benefits. Maltose and maltotriose are among the hydrolysis products of starch through amylase. However, according to Kiran et al. (2018), the application of amylase is limited due to its poor stability against high temperatures in industrial environment. Cellulase, on the other hand, is used in various industries such as textile, pulp, and paper production. It also plays a key role in production of bioethanol from lignocellulosic material. However, there is a need for cost reduction as well as modifying its temperature stability to higher one in order to make the process economically feasible (Sukumaran, Singhania and Pandey 2005). Then, inulinase catalyzes the hydrolysis of inulin, leading to the formation of D-fructose which is considered a safe sweetener for diabetic patients. Mainly, the sources of these enzymes are plants and vegetables, however, the production cost is high and it is difficult to obtain in sufficient quantity.

The protease, on the other hand, is the most studied enzyme. It accounts for $65 \%$ of the total worldwide sales of enzymes. According to Mehtani et al. (2013), proteases are needed in detergent, silk, food and pharmaceutical industries. In general, the optimal temperature and $\mathrm{pH}$ of most enzymes are $37^{\circ} \mathrm{C}$ and 7.4 respectively. However, they are denatured at higher temperatures and significant changes in pH (Singh et al. 2016). Compared with those obtained from plants and animals, microbial enzymes are more active and stable (Anbu et al. 2013). In addition, thermophilic microorganisms are adapted to live in high temperatures and growing optimally at a temperature of more than $45^{\circ} \mathrm{C}$.

According to Ifandi and Alwi (2018), most of the enzymes produced by thermophilic microorganisms are widely used due to their thermostability and ability to resist changes with respect to the physical and chemical factors happening during the industrial processes. Furthermore, the inulinase activity from mesophilic bacteria has been 
extensively studied, however, there is a need for a further study of inulinases from thermophilic bacteria. Also, studies regarding the isolation and production of carbohydrase and protease enzymes producing thermophilic microorganisms from diverse sources are currently gaining wider attention. Therefore, the aim of this study is to isolate and molecularly identify carbohydrase and protease producing Bacillus subtilis JCM 1465 isolated from the Penen Hot Springs in Deli Serdang District, North Sumatra, Indonesia.

\section{MATERIALS AND METHODS}

\section{Study area}

The location of the sampling site is on Penen Hot Spring ( $3^{\circ} 18^{\prime} 5^{\prime \prime} \mathrm{N}$ and $\left.98^{\circ} 38^{\prime} 41^{\prime \prime} \mathrm{E}\right)$, in Penungkiren Village, Sinembah Tj. Muda Hilir Subdistrict, Deli Serdang District, North Sumatra Province, Indonesia. The map of sampling site is shown in Figure 1.

The temperature and $\mathrm{pH}$ were measured during the sampling from 3 sites using a bottle sampler. About 100 $\mathrm{mL}$ of the water sample was collected into sterile screwcap tubes. Also, sediment samples were collected using Ekman Grab and then transferred into $100 \mathrm{~mL}$ sterile polyethylene bottles. Then, the samples were placed into the icebox and transported immediately to the laboratory for further analysis

\section{Enrichment and screening of carbohydrase and protease producing microorganisms}

The carbohydrase enzymes activity investigated in this study include; inulinase, amylase, and cellulose activity.
$1 \mathrm{~mL}$ of water sample and $1 \mathrm{~g}$ of sediment from each site were mixed in $9 \mathrm{~mL}$ Tryptic Soy Broth medium and incubated for 24 hours at $49^{\circ} \mathrm{C}$. Next, serial dilutions were carried out up to $10^{-3}$ of the water sample. From the last dilution, $0.1 \mathrm{~mL}$ of inoculum was placed on the surface of Tryptic Soy Agar in a petri dish and incubated at $49^{\circ} \mathrm{C}$ for 48 hours. The growing isolates were then purified by restreaking on the surface of the agar. The inulinase activity was screened by inoculating on the surface of the inulinase screening medium (Tryptic Soy Agar $+1 \%$ inulin powder). The clear zone around the microorganisms is an indication of inulinolytic activity (Tharun et al. 2017). Similarly, the amylase activity was screened using Tryptic Soy Agar supplemented with $1 \%$ starch. In line with the result of the study conducted to Kiran et al. (2018), the amylolytic activity is indicated by the formation of colorless hydrolytic zone after the plate is soaked with Lugol. Also, the CMC plate assay was used for the detection of cellulase producing isolates. To screen the cellulase activity, the plate was incubated at $48{ }^{\circ} \mathrm{C}$ for 6 days and the medium was overflown with Lugol solution. The formation of clear zone of hydrolysis was an indication of the degradation of cellulose (Mohammad et al. 2017). Then, the Skim Milk Agar was used to assess protease activity, with a clear zone surrounding the bacteria (Remigio et al. 2012).

\section{Biochemical and morphological characterization}

The biochemical characterization of isolates was conducted through citrate, catalase and motility tests, as well as the gelatinase activity. The morphol of the isolate was determined by Gram staining, while its morphological characterization was achieved by examination of colony shape, elevation, color, margin and edge of the colony.

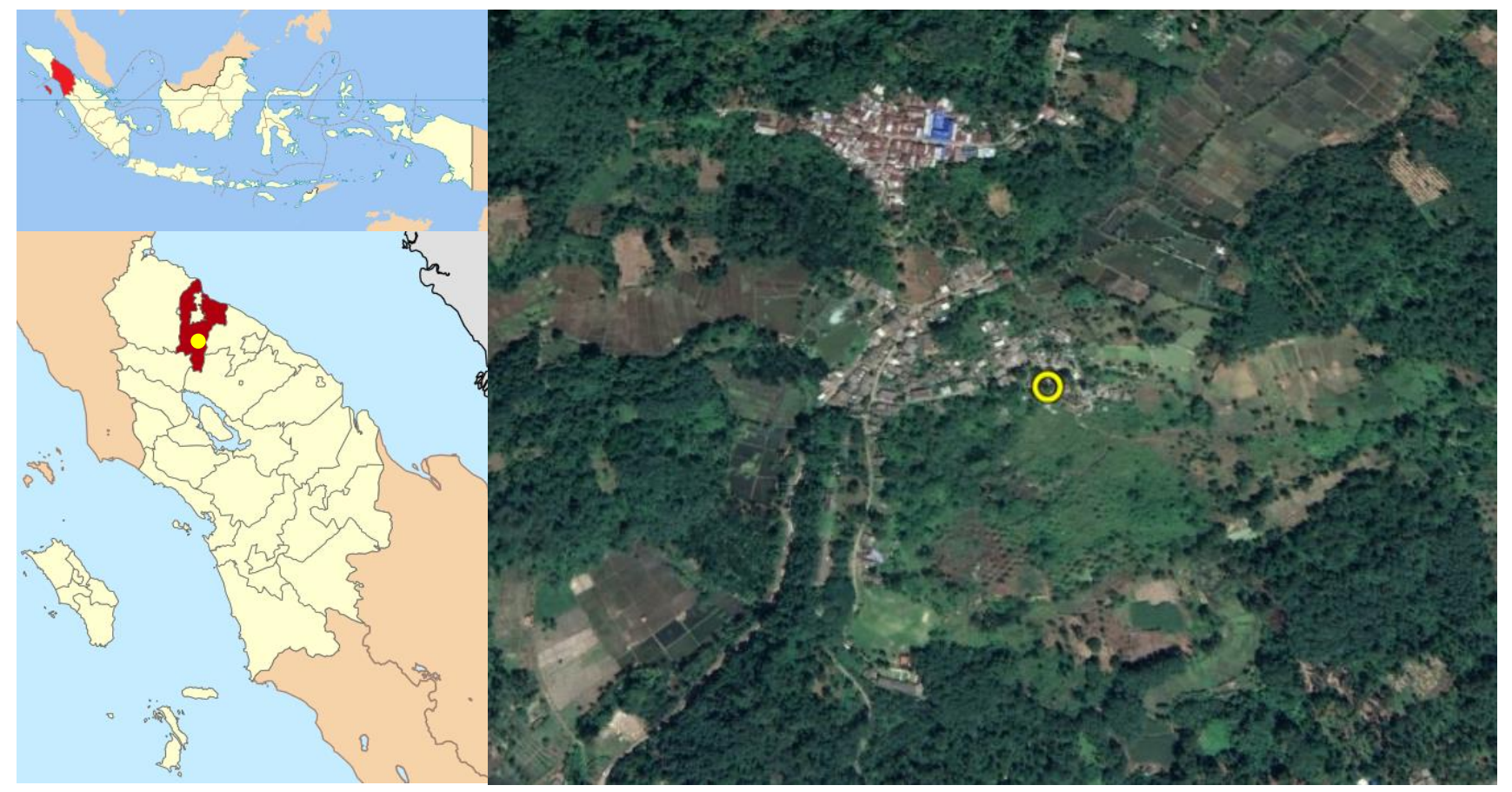

Figure 1. Location of sampling sites in Penen Hot Spring, Deli Serdang District, North Sumatra Province, Indonesia ( $3^{\circ} 185^{\prime}$ ” N and 9838'41” E) 
DNA isolation, 16SrRNA amplification, and sequencing

About 1 loopful, which is about $10 \mu \mathrm{L}$ of bacterial isolates were grown overnight and transferred into microtube $1.5 \mathrm{~mL}$. Then, $1 \mathrm{~mL}$ TE buffer was added and mixed until it was in the homogenous form. Then, the tube was centrifuged at 11,000 ref for 15 minutes. Next, lysozyme was added into the tube and incubated for 30 minutes at $37^{\circ} \mathrm{C}$. After which $125 \mu \mathrm{L}$ ammonium acetate 7.5 $\mathrm{M}$ was added and the tube was placed in ice for 10 minutes. Also, $500 \mu \mathrm{L}$ chloroform was added into the tube and it was shaken vigorously. The whole samples were then centrifuged at $11,000 \mathrm{rcf}$ for 10 minutes. The supernatant was removed into a new tube and isopropanol was added with ratio isopropanol: supernatant $=1 / 2: 1$. Next, the tube was inverted up and down several times until homogenous form was obtained. Again, the samples were centrifuged but at $18,000 \mathrm{rcf}$ for 10 minutes. The supernatant was removed and $500 \mu \mathrm{L}$ ethanol $70 \%$ was added and centrifuged again at 18,000 rcm for 10 minutes. Then, the supernatant was removed, and the pellet was wind dried. In addition, $50 \mu \mathrm{L}$ nuclease-free water was added into the tube. Then, the solution was used as DNA template for PCR. The program of PCR used in this study was: pre denaturation at $95{ }^{\circ} \mathrm{C}$ for 90 seconds, continued with 30 cycles consisting of denaturation at $95^{\circ} \mathrm{C}$ for 30 seconds, annealing at $55^{\circ} \mathrm{C}$ for 30 seconds, extension at 72 ${ }^{\circ} \mathrm{C}$ for 90 seconds, and final extension at $72{ }^{\circ} \mathrm{C}$ for 3 minutes. The primers used in this study were Primer $27 \mathrm{~F}$ : 5-AGA GTT TGA TCC TGG CTC AG-3' dan Primer 1492 R: 5-GGT TAC CTT GTT ACG ACT T-3. The sequence result was trimmed and assembled using BioEdit program, after which it was submitted to http://www.ncbi.nlm.nih.gov/BLAST so as to determine the homol of the microorganism.

\section{RESULTS AND DISCUSSION}

\section{Characterization of samples}

The sampling location was approximately $50 \mathrm{~km}$ from Medan city, with coordinate $3^{\circ} 18^{\prime} 6 \mathrm{~N}$ and $98^{\circ} 38^{\prime} 41 \mathrm{E}$. The $\mathrm{pH}$ and temperature measured at 3 location points before sampling are shown in Table 1.

\section{Isolation of carbohydrase and protease producing bacteria}

In this study, 11 isolates were screened for carbohydrase and protease activities. Those of carbohydrase investigated were inulinase, protease, amylase, and cellulose activities. From these isolates, only UTMP 12 showed maximum enzyme activities. The growth of UTMP 12 on Saboraud Dextrose Agar is shown in Figure 1.

The screening of carbohydrase and protease activities showed that UTMP 12 produced amylase, inulinase and protease activity based on the clear zone around the isolate on the screening medium. The carbohydrase and protease activity of UTMP 12 is shown in Figure 2.
The UTMP 12 was then analyzed further by biochemical and morphological characteristics. However, it showed a negative in citrate test, and gelatin hydrolysis. The UTMP 12 also showed non-motile activity. Based on morphol characteristics, it showed circular shaped, entire edge, convex elevation and creamy colored. Also, the Gram staining observation showed the UTMP 12 is negative and rod-shaped. The result of Gram staining is shown in Figure 3. The result of biochemical and morphological characteristics are shown in Table 2.

Based on 16S rRNA sequence alignment, UTMP 12 has a similarity with Bacillus subtilis strain JCM 1465, with homol of $99.72 \%$ and accession number NR_113265.1. Also, a phylogenetic analysis was generated, and the resulting tree is shown in Figure 4.

\section{Discussion}

Based on the temperature range and conditions for optimal growth, the microorganisms were classified as mesophils, psychrophiles, and thermophiles (Pandey et al. 2014). Thermophilic bacteria have the capacity to survive at temperatures above $45^{\circ} \mathrm{C}$ and are usually found in hot springs, deep sear hydrothermal vents and various geothermally regions of the world (El-Gayar et al. 2017). In this study, the temperatures of the samples, including in the water and sediment, were between $47-48^{\circ} \mathrm{C}$, hence, the bacteria isolated from these samples were categorized as thermophilic bacteria. Also, there are many factors affecting the tolerance level of thermophilic bacteria, these include; permeability, chemical stability of membrane lipids and GC contents. Similarly, there are more hydrogen bonds in GC base pair compared with AT base pair (Mehta et al. 2016). In addition, the $\mathrm{pH}$ observation showed that the sampling locations have neutral $\mathrm{pH}$. This is in line with the study conducted by Ifandi and Alwi (2018), which reported that thermophilic bacteria isolated from Bora Hot Springs in Central Sulawesi have optimum growth at $\mathrm{pH}$ $6.5-8$, indicating they were neutrophilic to alkalophilic bacteria.

Table 1. $\mathrm{pH}$ and temperature of the sampling site

\begin{tabular}{llll}
\hline & Site $\mathbf{1}$ & Site 2 & Site 3 \\
\hline Temperature $\left({ }^{\circ} \mathrm{C}\right)$ & 49.7 & 49.2 & 47.8 \\
$\mathrm{pH}$ & 7.5 & 7.0 & 6.6 \\
\hline
\end{tabular}

Table 2. Biochemical and morphol characteristic of UTMP 12

\begin{tabular}{ll}
\hline Characteristics & Result \\
\hline Citrate test & - \\
Catalase test & + \\
Gelatin hydrolysis & - \\
Motility & - \\
Shaped & Circular \\
Edge of colony & Entire \\
Elevation & Convex \\
Color & Cream \\
Gram staining & Rod, negative \\
\hline
\end{tabular}




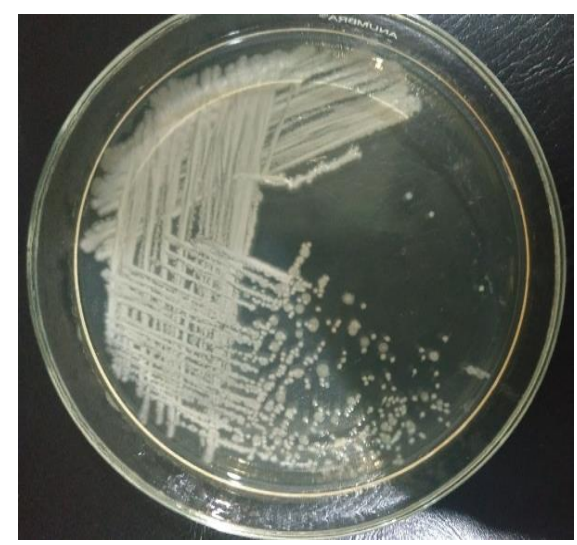

Figure 1. The growth UTMP 12 on Saboraud Dextrose Agar

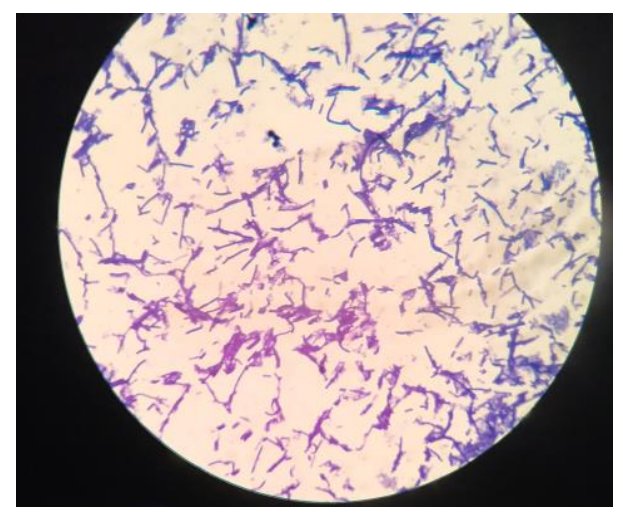

Figure 3. The result of Gram staining of isolate UTMP 12 under microscope with $1000 \mathrm{x}$ magnification. The bacteria has rodshaped morphol

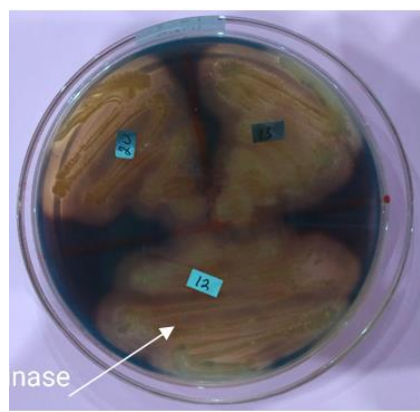

A

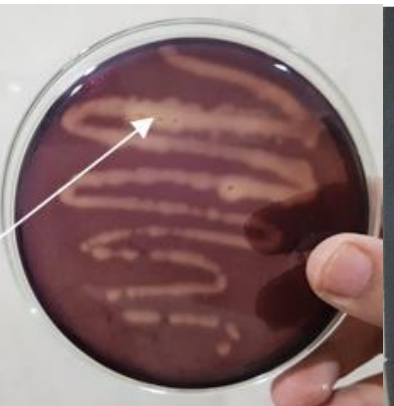

B

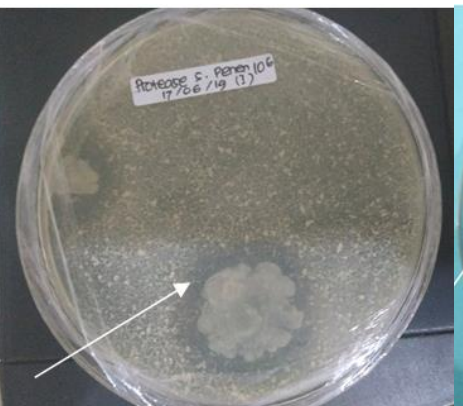

$\mathbf{C}$

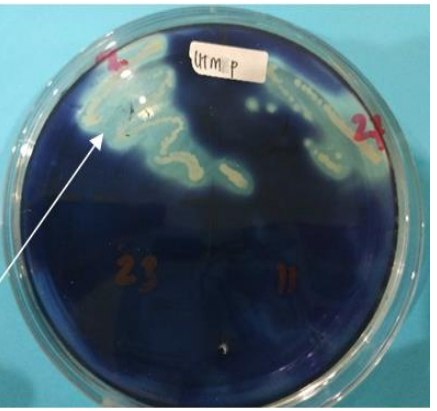

D

Figure 2. The carbohydrase and protease activity of UTMP 12, the arrow pointed at clear zone, indicating activity of enzyme. A. Inulinase activity, B. Cellulase activity, C. Protease activity, D. Amylase activity

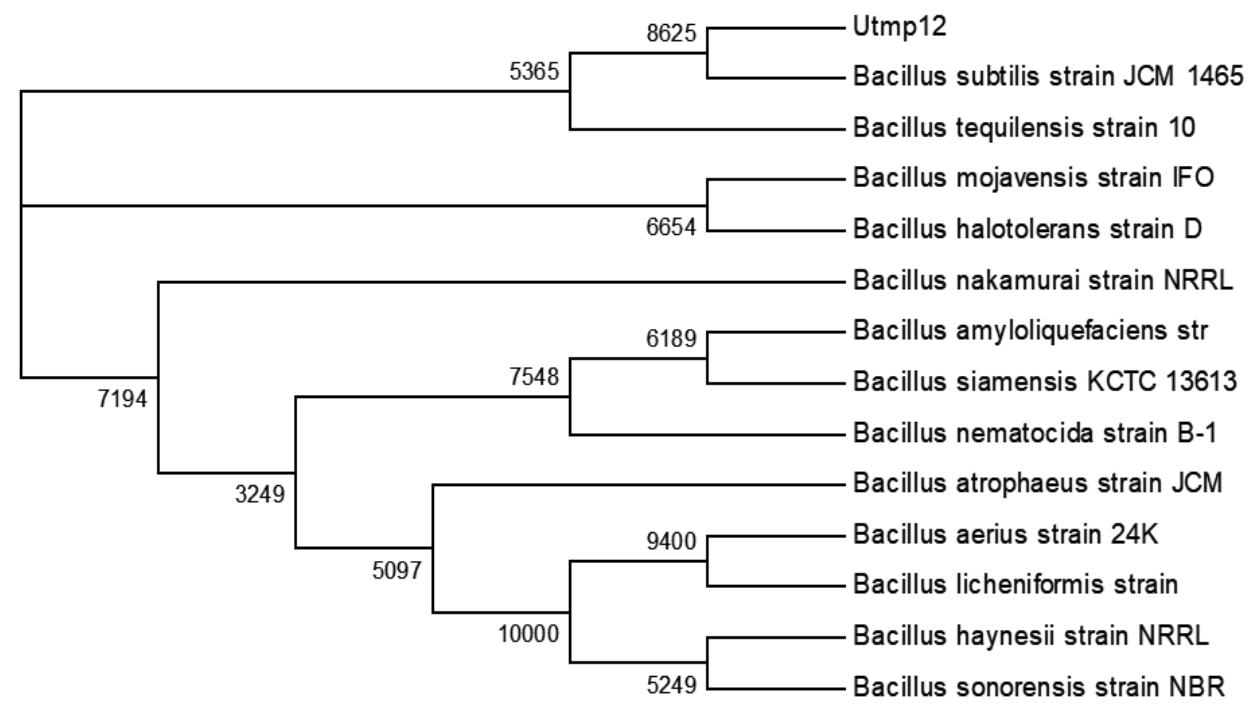

Figure 4. Dendrogram of UTMP 12 with 13 Bacillus species based on $16 \mathrm{~S}$ regional sequence. The box indicates a cluster that is closely related to high bootstrap values 
More so, Martinez et al. (2010) reported that thermophilic bacteria strain was isolated from enriched thermal water from Los Banos Hot Springs with $\mathrm{pH} 7$. Then, the phylogenetic tree for these different species of Bacillus indicated that the strain was closely related to $B$. subtilis strain JCM 1465. This result is in agreement with a study that reported the optimization of amylase production by thermophilic B.subtilis (Al-Johani et al. 2017). Additionally, Vijayalakshmi et al. (2013) reported that Bacillus subtilis produces a more stable protease enzyme compared with B. licheniformis.

Bacillus subtilis strain JCM 1465 showed a wide range of enzyme activities including carbohydrase and protease. The carbohydrase activities observed based on the results of this study include inulinase, amylase, and cellulase. These were conducted using Lugol iodine or rapid screening. Hence, the formation of colorless hydrolytic zone around the bacteria is an indication of the carbohydrase activities. Then, the clear zone around the colonies in starch and inulin medium is an indication that the starch and inulin have been hydrolyzed by the amylase and inulinase, whereas the dark blue zone is formed through the reaction between carbohydrate and iodine (AlJohani et al. 2017). Furthermore, several studies have been conducted regarding bacteria inulinase activities. The extracellular producing bacterium isolated from soil of Agave sisalana was identified as Bacillus sp. B5If, has the highest inulinase activity at $\mathrm{pH} 8$ and temperature of $55^{\circ} \mathrm{C}$, and was classified as thermophilic and alkaliphilic bacteria (Aruna and Hati 2014). Similarly, the bacteria isolated from thermal water samples of Velingrad, Bulgaria, was identified as Bacillus sp. SG7 and showed extracellular inulinase activity. The isolate was found to be grampositive, motile, aerobic and rod-shaped bacterium. Its optimum conditions were found at $\mathrm{pH}$ of $8.0-8.5$ and temperature of $55-60{ }^{\circ} \mathrm{C}$. In addition, the bacteria showed hydrolysis reaction against several sources of inulin namely chicory (Cichorium intibus), dahlia (Dahlia pinnata) and Jerusalem artichoke (Helianthus tuberosus) roots (Ivanova et al. 2018). Then, Bacillus stearothermophilus which best grows between $41-69^{\circ} \mathrm{C}$, produced thermostable exoinulinase, which is made up of $1.482 \mathrm{bp}$, and 494 amino acids (Liu et al. 2014). Another study reported that Bacillus $s p$. SG7 produces exo-inulinase. This enzyme has been purified and the molecular mass was estimated to be 56.000 $\mathrm{Da}$. The optimum $\mathrm{pH}$ needed to produce it was 7.0 and it is stable at temperature of $60^{\circ} \mathrm{C}$ (Gavrailov and Ivanova 2014). The genus of Bacillus is also known to synthesize $\alpha$ amylase enzyme, hence, it has the potential to dominate the enzyme industries. Additionally, the involvement of 3 species of Bacillus; B. subtilis, B. cereus and $B$. megaterium were reported in the production and medium optimization of amylase. It was reported that the optimum $\mathrm{pH}$ and temperature were 7 and $37^{\circ} \mathrm{C}$ respectively, indicating they were mesophilic bacteria (Viswanathan et al. 2014). In the same vein, the thermophilic Bacillus sp. strain SMIA-2 isolated from a local soil sample was reported to produce $\alpha$-amylase. Its optimum temperature was between $40-50^{\circ} \mathrm{C}$, while the optimum $\mathrm{pH}$ was 8.5 indicating it could be used in detergent industry (Carvalho et al. 2008). Suman and Ramesh (2010) reported that Bacillus sp isolated from a soil sample has optimum $\mathrm{pH}$ of 7.0 and temperature of $50^{\circ} \mathrm{C}$, indicating it is thermophilic in nature. Furthermore, the strain showed protease activities. A similar study was reported by Sharma and Aruna (2012) in which the isolated bacteria from milk powder was identified as Bacillus subtilis WIFD5. This bacteria showed maximum protease activities at $\mathrm{pH} 9$ and temperature of $55^{\circ} \mathrm{C}$. Alam et al. (2017) reported the bacteria isolated from a particular soil was identified as Bacillus subtilis with protease activities and molecular weight between 10-30 Kda. In addition, the crude enzyme was reported to have direct dehairing activity and with the ability to remove blood and curry stain from clothes, which is an indication that proteolytic microbial enzyme has the potential to be used in detergent and leather industry (Alam et al. 2018)

In conclusion, this is the first report on the isolation of thermophilic bacteria from hot spring in Penen Hot Springs, North Sumatra. The molecular identification based on the amplification of 16S rRNA and sequencing revealed that isolate UTMP 12 was Bacillus subtilis strain JCM 1465. This thermophilic bacteria showed carbohydrase and inulinase activities. However, this result can be investigated further for the characterization and production of industrially thermostable enzymes.

\section{ACKNOWLEDGEMENTS}

This research was supported by the Ministry of Research, Technol and High Education of the Republic of Indonesia through Collegiate Research Collaboration Grant Research with contract number: T/61/L1.3.1/PT.01.03/2019.

\section{REFERENCES}

Al-Johani NB, Al-Seeni MN, Ahmed YM. 2017. Optimization of alkaline A-amylase production by thermophilic Bacillus subtilis. Afr J Tradit Compl Altern Med 14 (1): 288-301. DOI: 10.21010/ajtcam.v14i1.31.

Alam G, Uddin E, Rahman S, Ahmad T, Karim R, Mahmood MS, Alam MS, Hossain J, Maitra P, Islam S. 2018. Protease activity of extracellular enzyme produced by $B$. subtilis isolated from soil. Intl $\mathbf{J}$ Environ Agric Biotechnol 2 (1): 382-388.

Anbu P, Gopinath SCB, Cihan AC, Chaulagain BP. 2013. Microbial enzymes and their applications in industries and medicine microbial enzymes and their applications in industries and medicine. Biomed Res Intl. DOI: 10.1155/2013/204014.

El-Gayar KE, Al Abboud MA, Essa AMM. 2017. Characterization of thermophilic bacteria isolated from two hot springs in characterization of thermophilic bacteria isolated from two hot springs in Jazan, Saudi Arabia. J Pure Appl Microbiol 11 (2): 1-9. DOI: 10.22207/JPAM.11.2.13.

Aruna K, Hati A. 2014. Optimization of Inulinase Production by Bacillus sp. B51f isolated from rhizosphere soil of Agave sisalana. Intl J Pure Appl Biosci 2 (3): 161-76.

Carvalho RVDe, Lívia T, Côrrea R, Caroline J, Ribeiro L, De Oliveira C, Lelis M, Martins L. 2008. Properties of an amylase from thermophilic Bacillus sp. Brazilian J Microbiol 39: 102-107.

Contesini FJ, De Alencar Figueira J, Kawaguti HY, Carlos P, De Barros Fernandes, De Oliveira Carvalho P, Nascimento G, Sato HH. 2013. 
Potential applications of carbohydrases immobilization in the food industry. Intl J Mol Sci 14: 1335-69. DOI: 10.3390/ijms14011335.

Gavrailov S, Ivanova V. 2014. Isolation and characteristics of a thermophilic Bacillus strain, producer of inulinase. J BioSci Biotech 83-94.

Ifandi S, Alwi M. 2018. Isolation of thermophilic bacteria from Bora Hot Springs in Central Sulawesi. Biosaintifika 10 (2): 291-97.

Ivanova V, Gavrailov S, Pashkoulova V. 2018. Purification of an exoinulinase from Bacillus sp. SG7. J Microbiol Biotechnol Food Sci 8 (1): 685-91. DOI: 10.15414/jmbfs.2018.8.1.685-691.

Kiran S, Singh A, Prabha C, Kumari S, Kumari S. 2018. Isolation and characterization of thermostable amylase producing bacteria from hot springs of Bihar, India. Intl J Pharma Med Biol Sci 7 (2): 28-34. DOI: 10.18178/ijpmbs.7.2.28-34

Liu GL, Chi Z, Chi ZM. 2014. Molecular characterization and expression of microbial inulinase genes. Crit Rev Microbiol 39 (2): 152-65. DOI: 10.1007/s00253-008-1827-1.

Martinez DLP, Gomez RC, Galbis DM, Chavez JAC, Alfaro GV, Oliart Ros R. 2010. Thermophilic bacteria from mexican thermal environments : isolation and potential applications. Environ Technol 31 (8): 957-66. DOI: 10.1080/09593331003758797.

Mehta R, Singhal P, Singh H, Damle D, Sharma AK. 2016. Insight into thermophiles and their wide-spectrum applications. 3 Biotech 6 (1): 1 9. DOI: $10.1007 / \mathrm{s} 13205-016-0368-\mathrm{z}$

Mehtani P, Sharma C, Chatterjee S, Bhatnagar P. 2013. Proteases: the industrial biocatalyst proteases : the industrial biocatalyst. IIS Univ J Sci Tech 2 (1): 1-12.

Mohammad BT, Al Daghistani HI, Jaouani A, Abdel-latif S, Kennes C. 2017. Isolation and characterization of thermophilic bacteria from Jordanian Hot Springs: Bacillus licheniformis and Thermomonas hydrothermalis isolate as potential producers of thermostable enzymes. Intl J Microbiol 2017: 1-12.
Pandey A, Dhakar K, Sharma A, Priti P, Sati P, Kumar B. 2014. Thermophilic bacteria that tolerate a wide temperature and $\mathrm{pH}$ range colonize the Soldhar $\left(95^{\circ} \mathrm{C}\right)$ and Ringigad $\left(80{ }^{\circ} \mathrm{C}\right)$ Hot Springs of Uttarakhand, India. Ann Microbiol. DOI: 10.1007/s13213-014-0921-0.

Remigio Z, William M, Olle H, Wilson P. 2012. Isolation and characterization of a protease-producing thermophilic bacterium from an African Hot Spring. Afr J Biotechnol 11 (62): 12571-78. DOI: 10.5897/AJB12.142.

Suman S, Ramesh K. 2010. Production of a thermostable extracellular amylase from thermophilic Bacillus species. J Pharmaceut Sci Res 2 (2): $149-54$.

Sharma S, Aruna K. 2012. Optimization of protease activity of thermophilic Bacillus subtilis WIFD5 isolated from milk powder. Biomed Pharmacol J 5 (1): 57-64.

Singh R, Kumar M, Mittal A, Mehta PK. 2016. Microbial enzymes : Industrial progress in 21st century. 3 Biotech 6 (174): 2-15. DOI: 10.1007/s13205-016-0485-8.

Sukumaran, Rajeev K, Reeta Rani Singhania, and Ashok Pandey. 2005. Microbial cellulases-production, applications and challenges. J Sci Res 64: 832-44.

Tharun S, Guttikonda K, Vanitha S, Anuradha K. 2017. Screening of inulinase producing bacteria from diverse sources. Biosci Discov 8 (4): 695-701.

Vijayalakshmi S, Ranjitha J, Devi Rajeswari V. 2013. Enzyme production ability by Bacillus subtilis and Bacillus licheniformis-a comparative study. Asian J Pharmaceut Clin Res 6 (4): 4-7.

Viswanathan S, Rohini S, Rajesh R, Poomari K. 2014. Production and medium optimization of amylase by Bacillus spp using submerged fermentation method. World J Chem 9 (1): 1-6. DOI: 10.5829/idosi.wjc.2014.9.1.76128. 